\title{
INTERNATIONAL AND LEGAL ASPECTS OF CITIZENSHIP ON THE BASIS OF ANALYSIS OF THE LEGISLATION IN KAZAKHSTAN AND GREAT BRITAIN
}

\author{
Aidana Otynshiyeva ${ }^{1 *}$, Alua Ibrayeva ${ }^{1}$, Joshua Castellino², Dina Baimakhanova ${ }^{1}$, \\ Akhilbek Baikenzheyev ${ }^{3}$ \\ Department of the Theory and History of State and Law, Constitutional and Administrative Law Al-Farabi Kazakh National \\ University, Almaty, Kazakhstan ${ }^{1}$; Law School, Middlesex University, London, United Kingdom²; Academy of National Security in \\ the Republic of Kazakhstan, Alma-Ata, Kazakhstan ${ }^{3}$
}

\begin{abstract}
The purpose of this article is to examine the international legal aspects of citizenship on the basis of the laws of Kazakhstan and the United Kingdom analysis. For this, the author used general theoretical and specific scientific investigation methods. As a result of the analysis, the author claims that the legal regulation of citizenship is carried out by each state independently. The legal regulation of citizenship is directly related to the migration of people, which has intensified in recent years in connection with armed conflicts and economic decline in some countries. The legal regulation of citizenship must correctly reflect the migration processes in order to prevent negative consequences for both the state and the individual in it. It has been revealed and justified that the legislation on the citizenship of Kazakhstan and the UK provides for a number of requirements for obtaining citizenship. There are two main ways to obtain citizenship: by birth or by naturalization. Based on the analysis, the author concluded that the legislation on the citizenship of Kazakhstan and the UK stipulates that citizenship is acquired and terminated by a specially prescribed legal procedure by the competent government authorities. Based on the analysis of Kazakhstan legislation, it was concluded that the methods of obtaining Kazakhstan's citizenship are: 1) by birth; 2 ) as a result of naturalization; 3 ) on the basis of interstate contracts of Kazakhstan; 4) on the grounds provided by the Law of Kazakhstan "On Citizenship". There are also ways to obtain UK citizenship under the British Nationality Act of 1981: 1) by birth; 2) by origin; 3) by naturalization; 4) by registration. Also, on the basis of a scientific approach to the issue of citizenship and its role in the existence of the state, the author concluded that bipatrism (multiple citizenship) adversely affects the state and carries a large risk to the state, including the loss of independence and sovereignty.
\end{abstract}

Keywords

Bipatrism, citizenship, naturalization, migration, acquisition of citizenship

\section{INTRODUCTION}

The problem of citizenship traditionally belongs to one of the key ones in the constitutional law of different states, including Kazakhstan and Great Britain. However, there is some uncertainty and controversy in the approaches to understanding the essence of citizenship in scientific publications. Traditionally, the concept of citizenship was related to the relationship between the individual and the state, guaranteeing citizens the legal status of full-fledged members of society with 
certain rights and duties $/ \mathbf{1} /$. There is also a point of view that the concept of citizenship is based on the notion of a limited society. It is usually believed that societies are sovereign social subjects, and the state at their center organizes the rights and duties of each member. Most of the basic social relations are regarded as current in the territorial boundaries of each society. The state has a monopoly of jurisdiction over the territory of society. It is assumed that the economy and the social class, as well as politics, culture, gender, etc., have a social structure. In aggregate, such relations constitute a social structure within which the life chances of each member of this society are organized and regulated $/ \mathbf{2} /$. In world science, the issue of treating bipatrism (multiple citizenship) has not been resolved. Numerous conflicts arise in the legislation on the citizenship of different countries due to the lack of a unified scientific approach to this problem. The practical value of the article is the possibility of using the results obtained to improve the constitutional legislation, the norms of which contain questions of citizenship, in law enforcement activities when obtaining or denying citizenship. The study and justification of the need to abandon bipatrism is the contribution to world science.

\section{MATERIALS AND METHODS}

In the course of the research, the author used both general theoretical and specific scientific methods of cognition. Evolution of citizenship, as well as certain problems of citizenship, are viewed as parts of the objective process conditioned by the development and change of social relations. The research is based on a historical method, a formal and dogmatic (special juridical) method, a method of specific legal research, a method of logical analysis, and other methods and techniques. The author used statistical data and sociological research data, which relate to questions of citizenship in the legislation of Kazakhstan and the United Kingdom. The sociological method was used to study the problems of citizenship in Kazakhstan and the UK, as it allows assessing the adequacy of legislation. A comparative-legal (comparative) method was also used. In combination with other methods, it allowed to solve the tasks set by the author to assess the norms of the legislation on the citizenship of Kazakhstan and the United Kingdom.

\section{LITERATURE REVIEW}

Citizenship is necessary to form a civil society and to develop the state. Human rights and freedoms are ensured through the institution of citizenship. This article examines the issues of the legal regulation of citizenship in the legislation of the Republic of Kazakhstan and the United Kingdom. First, let us consider the main points of view of other authors on the concept of citizenship, its nature and features.

Ye.S. Smirnova says that with regard to the institution of citizenship, it is the political aspect that is decisive, since, being connected with sovereignty, the right to citizenship is the complex that allows a person to realize their possibilities in full $/ 3 /$. A.A. Nepomnyashchaya adds, that only as a citizen of a certain state, a person has all the fullness of rights and freedoms, including the right to participate in the political life of the state, to elect and be elected to government bodies and local governments, which is the determining factor for states positioning themselves as democratic /4/. Other authors say that citizenship entails the ability to share public and common interests throughout the entire process that knowledge can offer. It is the ability to collect various information from different sources, which means free information, and to participate in collective events $/ 5 /$. Citizenship is not a static object, but a permanent relational process that determines the roles, hierarchies and relations in capitalist society and which changes with the change in the territoriality concepts $/ \mathbf{6} /$. According to the very idea of citizenship, a person can be considered as a citizen only if they are able to become an active subject of historical and socially significant processes in critical time for their community or state $/ 7 /$. The right to citizenship, formalised in Paragraph 1 of Article 15.1 of the Universal Declaration of Human Rights of 1948, Part 3 of Article 24 of the International Covenant on Civil and Political Rights of 1966, Paragraph 1 of Article 7 of the Convention on the Rights of the Child, 1989 /8/. As Ebzeyev B.S. believes the acquisition of citizenship is one of the main subinstitutions of the institution of citizenship. The legal regulation of the acquisition of citizenship is carried out by each state independently, which follows from the principle of state sovereignty and is universally recognized in science provision. In the entire post-Soviet space, citizenship is 
Aidana Otynshiyeva, Alua Ibrayeva, Joshua Castellino, Dina Baimakhanova, Akhilbek Baikenzheyev: INTERNATIONAL AND LEGAL ASPECTS OF CITIZENSHIP ON THE BASIS OF ANALYSIS OF THE LEGISLATION IN KAZAKHSTAN AND GREAT BRITAIN Media, Culture and Public Relations, 8, 2017, 1, 72-84

defined as a stable political and legal relationship between a person and the state, expressing the totality of mutual rights and obligations /9/. G.Yu. Balgimbekova points out that in the Republic of Kazakhstan citizenship is fixed in the system of normative and legal acts. This system can be regarded as a complex of political and legal acts that consolidate the rights and duties of the state and the individual. Political and legal acts include the Declaration on State Sovereignty, the Constitutional Law on State Independence, and the 1993 Constitution of the Republic of Kazakhstan, which elaborated the principles of Kazakhstani citizenship. In the legal form, Kazakhstani citizenship is formalised in the Constitution of the Republic of Kazakhstan and the Law on Citizenship of 1991 /10/. At the same time, some scientists say that Kazakhstani citizenship is acquired in two main ways - by birth and as a result of admission to citizenship /11/. Upon gaining independence in 1991, Kazakhstan granted citizenship to all people who lived within the borders of the country at that time, although most countries of the former USSR granted civil rights only on ethnic grounds. Kazakhstan has focused on creating a political and civilian national identity in which all people enjoy the benefits of citizenship /12/. Kazakhstan is a multiethnic state, like many other similar countries, which is not surprising in the era of globalization. The population of Kazakhstan on March 24, 2017, according to statistics, is $18,106,096$ people $/ \mathbf{1 3} /$. Since 2014 there is the migration outflow from Kazakhstan with departure for permanent residence in other states. In a comparative analysis, for the four months from January to April 2016, 6753 people departed, 3045 arrived, the negative balance of migration was 3708. Compared to 2015, for the indicated months, this number was: 5882 departed, 4748 arrived, and 1134 - balance of migration /14/. In the Concept of the Legal Policy of the Republic of Kazakhstan for the period from 2010 to 2020, approved by the Decree of the President of the Republic of Kazakhstan of August 24, 2009, it is emphasized that in the process of further implementation of the state of law principles in the country, it is important, on one hand, to achieve the maximum possible assurance of Constitutional rights and freedoms of man and citizen implementation. On the other hand, it is also important to achieve unconditional and exhaustive fulfillment of constitutional duties by all state bodies, officials, citizens and organizations $/ \mathbf{1 5} /$. Scientists are united in the opinion that the modern period of the institution of citizenship development is presented as a process of improving the constitutional and legal norms regulating it. In this period there is a process of development and improvement through the introduction of changes and additions to the laws on citizenship, as well as by developing constitutional law. At present, citizenship in the Republic of Kazakhstan is determined through constitutional and legal norms that determine the basis of the organizational and legal mechanism for regulating citizenship. They determine the construction and functioning of the system of state bodies regulating the functioning of the institution of citizenship /16/. Citizenship, which is the legal status of belonging, associated with an array of rights, is traditionally associated with the notion of the state. The EU citizenship, which follows the derivative logic of ius tractum, relies on the nationality of the member states of the European Union /17/. In 1992, after the formation of the European Union, all citizens of the Member States obtained EU citizenship, retaining their national citizenship. In countries, there are different terms, meaning a person's belonging to the state. In the Anglo-Saxon legal system, the term "the national" (a person belonging to the nation) is used simultaneously with the terms "the citizen" and "the subject". A lot of such terms were spread in the states that had colonies. The term "citizenship" was used to mean full-fledged citizens. European citizenship is not only a membership in the state. This is a relationship that governs the behavior (of the subject) of the position that consists of it. The essential difference between citizenship and membership is that while the latter regulates behavior within social groups, citizenship is behavior towards social groups that constitute the political body of society /18/. As for the state's participation in the formation and implementation of the content of citizenship, the UK occupies a moderate position, holding power at hand and taking responsibility where it deems necessary, leaving it for professionals and migrants otherwise. This symbolizes its liberal approach to management, as well as the conceptualization of citizenship as a matter of civil society /19/. S. Mantu notes that the British 
Aidana Otynshiyeva, Alua Ibrayeva, Joshua Castellino, Dina Baimakhanova, Akhilbek Baikenzheyev: INTERNATIONAL AND LEGAL ASPECTS OF CITIZENSHIP ON THE BASIS OF ANALYSIS OF THE LEGISLATION IN KAZAKHSTAN AND GREAT BRITAIN Media, Culture and Public Relations, 8, 2017, 1, 72-84

Citizenship Institute itself included British citizens, British overseas citizens, British foreign citizens, British protected individuals and British themselves $/ 20 /$. In the UK, there was a relatively quiet period in terms of policy on citizenship following the 1981 Law on British Citizenship. However, several recent events have emerged from the argument that multiculturalism has failed and that communities live in parallel lives. For example, the Citizenship Act of 2002, the 2002 Law on Asylum and Immigration require applicants for British citizenship to pass an English test, followed by citizenship ceremonies and an oath of allegiance to the Crown. Then, in the Law on Borders, Citizenship and Immigration, the concept of test for citizenship was introduced in 2009. Was put forward a requirement for an active citizenship, while the voluntary offer would speed up the application process $/ \mathbf{2 1} /$. The UK has realized that it is a long-term immigration country and often defines itself as a multiethnic nation based on its colonial history and the Commonwealth system. However, after the enlargement of the EU, and especially its expansion to the east, concern over immigration has increased. In accordance with a more strict immigration policy, the British government defines British citizenship as a "privilege, not a right" and calls for the development of advanced language skills and knowledge about British culture. In theory, citizenship is more valued if it is earned, not given. The selection criteria for becoming a citizen of the United Kingdom through naturalization became more stringent in October 2013. Along with some uncertain characteristics ("good character" and "sound spirit"), candidates wishing to live in the UK must be over 18 years old and have a test that proves the knowledge of English and life in the UK /22/.

\section{4. $\quad$ RESULTS}

The purpose of this study is to characterize the international legal aspects of citizenship based on an analysis of the laws of Kazakhstan and the United Kingdom.

To date, citizenship is a basic human right, as evidenced by Article 15 of the Universal Declaration of Human Rights. The presence of appropriate citizenship gives a person, and therefore, a citizen of the country concerned, a set of rights that may differ in different countries.
Such people have rights only in relation to the country concerned, confirming their legal relationship with the citizenship of such a person. Thus, the state establishes various rights and obligations, as well as their scope, depending on whether the person is a citizen of that particular country or not. Given that the state is not in a position to offer the same rights to all persons, for such persons as stateless persons, refugees, internally displaced persons, despite the fact that the same rights are established, in any case, the rights and obligations in accordance with the Constitution of this country will differ from the rights and duties of its citizens. For example, a set of relevant rights of citizens associated with the political life of the country (the right to elect and be elected). Considering such a broad concept as "citizenship" it is worth noting that this legal category contains elements of constitutional law in the first place, but it is possible that for the formation of a full, correct understanding and application of this category, the norms of other spheres of regulation, in particular, the norms of migration, labor legislation have influence on it. In addition to the constitutional fixing by each state, citizenship is determined by special national laws, its concept, principles of acquisition or loss. At the same time, its importance and correct application in practice is also influenced by international, both public and frequency law, which is associated with the high importance of this spectrum of legal relations throughout the world. The constitutions of the world countries determine the order of application and the priority of international norms over national ones. As a rule, the norms, fixed by the Constitution, take precedence over the norms of not only national legislation, but also over the norms of international treaties. In turn, the norms of international law dominate the norms of national legislation. Norms of both national legislation and international law are aimed at the need to establish legal and political relations of each person with the country concerned. Because of this regulation, countries take political responsibility for its actions before other countries or international organizations. Comparison of the legal systems of Kazakhstan and Great Britain, namely the norms of legislation that regulate the issues of citizenship, makes it possible to understand that different countries of the world regulate citizenship issues in different ways. The 
presence of significant contradictions in the legal systems of different countries to each other in matters of regulating citizenship, contributes to the emergence of global problems, in particular, multi-citizenship (bipatrism). International treaties aimed at resolving the conflict of legal norms cannot always help with the solution of those.

Citizenship is one of the main institutions of constitutional law. Hence the meaning of citizenship, the Constitution of the Republic of Kazakhstan (from 1995) included this institution in the context of section 2 of "Man and citizen". According to Article 10 of the Constitution of Kazakhstan, citizenship of the Republic of Kazakhstan is acquired and terminated in accordance with the procedure established by law, is indivisible and equal regardless of the basis for its acquisition. A citizen of the Republic of Kazakhstan cannot under any circumstances be deprived of citizenship, the right to change his citizenship and cannot be expelled from the territory of Kazakhstan /23/. At the same time, as Senator Ansar Musakhanov stated, Kazakhstan undertakes confident and new steps towards democratic development in these difficult conditions, when the world development is changing so rapidly, the constitutional reforms have been supported, both by Kazakhstanis and by world experts. In this regard, he supported the proposals of Senate of the Parliament of Kazakhstan Georgiy Kim to supplement Paragraph 2 Article 10 of the Constitution with the following sentence: "Deprivation of citizenship is allowed only by a court decision for the commission of terrorist crimes, as well as for causing other grave harm to the vital interests of the republic" /24/. It is worth supporting such a view, since global terrorism affects all countries today. And as practice shows, terrorists are not individuals without citizenship, on the contrary. And very often they are emigrants who have several nationalities. For example, the recent act of terrorism in Stockholm was committed by a Swedish citizen, an emigrant from Uzbekistan. Who simultaneously was a citizen of Uzbekistan. The right to citizenship or its change in the Republic of Kazakhstan, as in most countries, is regulated by the Constitution of the country. The Constitution of the Republic of Kazakhstan, national legislation and international treaties of the Republic of Kazakhstan define all the rights, freedoms and duties of citizens of Kazakhstan, also applicable to persons who are not citizens of Kazakhstan or persons who are on its territory. An exception may be provided for by the relevant legislation. Issues of citizenship in Kazakhstan are regulated by the special Law "On Citizenship" of December 20, 1991. This Law determines that the citizens of Kazakhstan are the persons who: 1) on the day of entry into force of this Law, that is, before March 1, 1992, permanently reside on the territory of the Republic; 2) obtained citizenship in accordance with the rules and requirements specified by this Law. Acquisition of citizenship in the Republic of Kazakhstan is possible by birth, acceptance of citizenship by a person, that is, the implementation of naturalization or acquisition of citizenship on the grounds defined by international treaties and relevant agreements of the Republic of Kazakhstan. Particular attention should be paid to legal relations regulated by the Law on Acquiring the Citizenship of the Republic of Kazakhstan by Birth. This legal category is based on such principles as "the right of blood" and "the right of soil." According to the principle of "blood rights" a child who was born both in the territory of the Republic of Kazakhstan and in any other country will be considered a citizen of the Republic of Kazakhstan if at the time of his birth his parents are also citizens of Kazakhstan and permanently reside on the territory of the country. In the event that parents are citizens of the Republic of Kazakhstan, and at the time of the child birth permanently reside in the territory of another country, the nationality of the child is determined by their common written consent. In this case, it is necessary to take into account the norms of both international agreements and the national legislation of the country where the parents of the child reside. A fairly frequent case is the situation where only one of the parents is a citizen of the Republic of Kazakhstan at the time of the birth of the child. In order for a child to acquire the citizenship of the Republic of Kazakhstan, he must be born on its territory. If a child is born outside the country, one of the parents must prove that at the time of the birth of the child his permanent residence was the territory of the country. At the same time, such requirements are not applied if at the time of the birth of the child one of the parents is a citizen of the Republic of Kazakhstan, and the other is a stateless person. 
One of the institutions of citizenship in the Republic of Kazakhstan is the termination of citizenship. Permanent residence of a citizen of the country outside the Republic is not determined by the grounds for the termination of citizenship. The Law of the Republic of Kazakhstan "On Citizenship" determines that the only reason for the termination of citizenship are the withdrawal from citizenship or its loss on the grounds determined by this Law. The Law "On Citizenship" of the Republic of Kazakhstan also guarantees the right to prohibit the extradition of a citizen of Kazakhstan to another country, exceptions to which can also be determined by international agreements of the Republic of Kazakhstan. Guarantees for the protection of civilians outside Kazakhstan are established in Article 11 of the Basic Law of Kazakhstan, according to which a citizen of the Republic of Kazakhstan cannot be extradited to a foreign state unless otherwise provided for by international treaties of the Republic. The Republic guarantees the protection and patronage of its citizens outside its borders /25/. The legal regulation of legal relations of citizenship in the UK is somewhat different from the legal regulation of citizenship in the Republic of Kazakhstan, which is explained by the presence in the country's legal system of case law. A special influence on the formation of special regulation of citizenship in the territory of Great Britain is also connected with the historical formation of the colonial character of the country, as a result of which the commonwealth exists between the former colonial countries today. Before the adoption of a number of special laws aimed at regulating citizenship, which began in 1914, the principle of the Common Law doctrine of allegiance operated in the country for a long time. A significant contribution to the legal regulation of citizenship in the UK was the adoption in 1948 of a large-scale special Nationality Act (British Nationality Act, 1948). Despite the adoption of the new Nationality Act in 1981 (British Nationality Act, 1981), the Nationality Act has been in effect since 1948 and still has its significance in the right field of regulations. In this connection, when applying the legislation governing the legal relationship of citizenship, the provisions of both laws should be taken into account. Due to the development of social and migration relations, the Nationality Act of 1948 introduced significant changes, through which the Law has already begun to regulate the issues of citizenship in the UK in a new way. Thus, since 1964, the norms of this Law establish that citizens of the country are people who, by the time the Law on Nationality came into force in 1981, were born in the UK, that is, before January 1, 1983. Due to the formation of such a link between the laws of 1948 and 1981, the legislation on citizenship formed a solid legal basis for applying to legal norms in judicial practice for many decades. The Nationality Act of 1981 applies concepts such as "nationality", which characterizes citizenship as a certain legal relationship between a British citizen both with the United Kingdom itself, and with the entire Commonwealth of former colonies. Also, the concept of "citizenship" characterizes the legal relationship between a citizen of the country and directly with the United Kingdom and its dependent territories. Depending on the territorial affiliation in the UK, the Nationality Act of 1981 defines the following three categories of citizenship: the citizenship of the United Kingdom of Great Britain and Northern Ireland (British Nationality), the citizenship of the British Overseas Islands (British Overseas Nationality), and the citizenship of British dependent territories (British Dependent Territories Nationality). Most of the UK population are citizens of the United Kingdom of Great Britain and Northern Ireland. It is this category of citizens that has the right to freely leave and enter the country, as well as a number of other rights and freedoms. UK national legislation regulates such methods of obtaining British citizenship:

1) by birth (a child born in the UK is considered to be a citizen of the country if one of his parents is a British citizen or has a permanent residence in the country);

2) by origin (a child born outside the UK is considered a British citizen if one of his parents is a British citizen by birth);

3) by naturalization (the correspondence of an adult applicant for British citizenship to the requirements of the Nationality Act since 1981. Requirements for a person wishing to obtain British citizenship may include, for example, compulsory English or Scottish knowledge, a permanent residence on the territory of the United Kingdom, royal service and the like. When registering a marriage between a British citizen and a citizen of another country, in the case of the 
Aidana Otynshiyeva, Alua Ibrayeva, Joshua Castellino, Dina Baimakhanova, Akhilbek Baikenzheyev: INTERNATIONAL AND LEGAL ASPECTS OF CITIZENSHIP ON THE BASIS OF ANALYSIS OF THE LEGISLATION IN KAZAKHSTAN AND GREAT BRITAIN Media, Culture and Public Relations, 8, 2017, 1, 72-84

latter having a desire to get British citizenship requirements may be somewhat lessened);

4 ) by registration (in case of registration of a minor, if he had such a right, but he did not use it for various reasons; registration of an adult living in another country but under British protection and entitled to British citizenship in accordance with law on citizenship of 1948; registration of an adult person who is a citizen of the British dependent and overseas territories).

Since 2002, new rules for determining citizenship come into force in the UK. This was facilitated by the adoption of the new Act on Citizenship, Immigration and Asylum. This Act granted powers to the Secretary of State for Internal Affairs to deprive British citizenship of persons if in his opinion they inflicted or could pose a threat to the country. At the same time, taking into account the provisions of the International Convention on the Reduction of Statelessness of 1961, such powers of the Secretary of State had their limitations - he could not deprive a person of citizenship if this would lead to the person's being stateless. The provisions of the Convention define the prohibition of any country being its participant, commit actions that lead to the loss of a person's citizenship. In this connection, this authority of the Secretary of State could automatically apply exclusively to persons who were bipatrides.

Since 2004, in the UK, at the legislative level, there has been an attempt to resolve the issues of the implementation of the procedure for deportation and forfeiture of British citizenship by such persons. And the task was to regulate the implementation of both actions by state bodies at the same time. In this connection, the Citizenship, Immigration and Asylum Act of 2002 is amended accordingly. As a result, a person may be deprived of British citizenship with simultaneous deportation of such a person. If a person is deprived of British citizenship and at the same time is a citizen of another member state of the $E U$, then that person is subject to the appropriate legal regime for his stay in the territory of the United Kingdom. However, in the overwhelming majority of cases, such measures are applied to persons who are not citizens of EU member states. In this connection, a person deprived of citizenship becomes a third party, which is subject to the rules of stay on the territory of the country provided for foreigners, including various migration control procedures. There were cases when the order for the deprivation of citizenship was submitted by the Secretary of State at the time when this person was officially outside the country.

The emergence of even stricter rules and the expansion of the rights of state bodies to deprive individuals of British citizenship was facilitated by the events in London in 2005 related to terrorist acts. The Prime Minister of Great Britain declared anti-terrorist measures, including the deprivation of British citizenship and the corresponding deportation of persons.

In 2002, the government introduced a radical change in British law, according to which even "natural" and not only naturalized people could become victims of losing their citizenship. Section 40 (3) of the Citizenship, Immigration and Asylum Act, 2002, was amended to allow the Secretary of State to deprive anyone of citizenship if he or she has ascertained that he or she has done something "that is causing serious harm to vital interests" of the United Kingdom /26/.

Given the granting of active suffrage in the UK to the citizens of the Irish Republic, the latter began to enjoy a special status. In parallel with the development of economic legal relations in connection with the signing on February 7, 1992 by the European Community of the Maastricht Treaty, citizens of EU member states were granted the right of free entry into the territory of the United Kingdom. In connection with the participation of Great Britain in the EU, the legal regulation of the legal relations of the country, including on issues of citizenship, is regulated not only by national legislation, but also by European legislation. As for naturalization in the UK, it should be noted that the very concept of naturalization hints at the fact that becoming a citizen is a process of acquiring the natural essence of a national group. However, if the national category is significant, it is both discrete and impenetrable. In this sense, naturalization is a process of nationalization /27/. Naturalization is the acquisition of British citizenship by someone who has (or continues to have) foreign citizenship. There are several ways to naturalization. Adults may apply for British citizenship at least after five years of living in the UK or through marriage to a British citizen (with a residence in the UK for three years as a spouse or a civil partner). In addition to living 
requirements, naturalized citizens must meet the requirements of "good character", the ability to communicate in English (or Welsh or Scottish) and take the test "Life in the UK" /28/. Reforms in legislation relating to the process of obtaining British citizenship by migrants are part of a social cohesion program. This policy with regard to citizenship is related to the policy of ownership and management of national borders /29/.

The test "Life in the UK" is part of the government's actions on immigration control. It was introduced by the government, headed by Prime Minister Tony Blair. All applicants for "permanent settlement" or naturalization need a successful passing of tests demonstrating a satisfactory knowledge of English and knowledge of British culture /30/. The British citizenship test was introduced as one of the new procedures aimed at addressing the perceived problems of integration and social cohesion in migrant communities $/ \mathbf{3 1} /$.

"Like the mass denationalisation of disadvantaged groups, the current practice of annulment of citizenship in the UK is a phenomenon directed almost exclusively at Muslim men, although their numbers are relatively small $/ 32 /$.

The law determines that a person may be deprived of British citizenship in the event of their renunciation of citizenship or as a result of their deprivation by the state authorities of persons who have obtained British citizenship by naturalization or registration under statutory grounds.

Moreover, when deciding on the termination of British citizenship, the State Secretary of Internal Affairs also takes into account the term of validity of citizenship.

Global migration and the search for diverse racial, ethnic, cultural, linguistic and religious groups for recognition, civil equality and structural integration in their national states made it difficult to obtain citizenship in countries around the world. In a number of countries, including the United Kingdom, nationalism and the movement towards social cohesion arose in response to globalization and growing ethnic, cultural, linguistic and religious diversity. For European States, such as England, it is difficult to combine citizens of Muslim nationality in their cultural, social and civic life /33/.
In the last decade, there has been an explosion of "immigrant protests," the political mobilization of illegal migrants and migrant activists. In this regard, you need to critically approach the understanding of citizenship /34/.

The British vote on June 23 (Brexit) sent uncertainty to European integration, including to European citizenship. European citizenship derives from national citizenship, to which it is added, not replacing it /35/. Pluralism in matters of culture, national identity and citizenship was central to Brexit /36/.

On the voting (Brexit), the British primarily wanted to protect themselves from the influx of refugees because of the EU's too loyal policy towards migration issues.

The large-scale increase in bipatrides, that is, persons with several nationalities, is primarily due to the increased influx of refugees into European countries in recent years. This is due to the fact that countries provide refugees with asylum, and eventually allow them to obtain citizenship through naturalization. Due to the fact that such persons are not required to give up their previous citizenship, and the number of bipatrides is increasing. In such cases, obtaining the status of bipatride is not the primary goal of refugees. At the same time, as practice shows, today a significant part of society consciously seeks to have dual citizenship. This social status gives such persons the opportunity to belong to two or more different states, which is advantageous by the existence of various kinds of rights, freedoms and benefits. In this regard, multiple citizenship causes negative and criticism from scientists, is an undesirable phenomenon and is widely discussed at the level of both international organizations and state bodies of many countries.

In addition, one should take into account the fact that multiple citizenship violates the principle of the citizen's individual belonging to the state, especially if there are conflicts and inconsistencies between the countries themselves both in the legal field and at the level of economic and social development. In the event of a serious conflict between countries, a negative situation can directly threaten such a citizen in the form of expressing his distrust of one of the countries.

Since citizenship is associated with the state, citizenship is associated with the Motherland, the Fatherland and with patriotism. 
Consequently, citizenship, civic consciousness and patriotism are elements of civil identity. Civil identity unites the population, it is the cementing basis of social integration $/ 37 /$.

The refusal of dual citizenship is enshrined in Paragraph 3 of Article 10 of the Constitution of Kazakhstan, where it is written that the foreign citizenship of a citizen of the Republic is not recognized /38/. This is a positive factor for Kazakhstan and can serve as an example for other countries, including Britain, whose citizens at the referendum (Brexit) announced their desire to withdraw from the European Union. The experience of many successful economies of the world shows how important the role in the formation of statehood is played by the factor of forming the sense of belonging of each citizen of Kazakhstan with his homeland, strengthening the sense of patriotism, which naturally leads to an increase in the level of civil identification among the population of the country /39/. President Nazarbayev made an especially persistent attempt to repatriate the Kazakhs. Including making an exception to his ban on the dual citizenship. This outraged the Russian population of Kazakhstan, as they urged Nazarbayev to allow them to have both Russian and Kazakh citizenship. Repatriated Kazakhs were allowed to retain dual citizenship of both former countries and Kazakhstan, although dual citizenship is prohibited for everyone else. Many ethnic Russians believe that this was a deliberate act aimed at suppressing any devotion to Russia or the former USSR and forcing ethnic Russians to unite with Kazakhstan and to an ethnic Kazakh way of life /40/.

\section{DISCUSSION}

The article examines the international legal aspects of citizenship based on the analysis of the legislation of Kazakhstan and the United Kingdom. The author considers the results of this research to be justified from the theoretical and practical point of view. One of the components of the concept of citizenship is proposed to define the category of awareness and understanding of legal relations between a citizen and the state. It is also necessary to take into account and determine such characteristics of citizenship as sympathy and attachment to one's state and its political system, psychological awareness of oneself as a citizen, attraction of a citizen to the political life of the country. Citizenship as a socio-legal institution develops at the country level. The formation and development of citizenship as a part of the modern legal field will depend on the level of political and economic development of the country, which is ensured by a complex of rights and freedoms both from the state and from each citizen. It is supported by responsibility for actions or inaction on the part of the subjects, causes damage to guaranteed interests. Was studied the negative impact of such a phenomenon as bipatrism on the international climate of legal relations between countries and their citizens. It is proposed to consider multiple citizenship as an unnatural factor that limits and weakens the social and economic level of the country's life, undermines its security and sovereignty, and also destroys the constitutional importance of such concepts as "citizenship" "nation", "people". Some other experts believe that dual citizenship "de-jure" (and only "de-jure") has significant advantages for both the individual and the state, since: 1) the state itself decides with which countries it is permissible and even profitable to have agreements on the recognition of dual citizenship; 2) only in this case, the participants of the relevant international treaty have the opportunity to neutralize the maximum number of negative consequences of dual citizenship; 3) through their citizens, the bipatrides, living in the territory of the state of their second citizenship, countries strengthen friendly ties among themselves; 4) the scope of rights for individuals becoming bipatrides -is significantly increased de-jure (freedom of movement between states, the possibility of diplomatic protection on the territory of third countries by both states of their citizenship, the possibility of acquiring real estate in both states of their citizenship), and human and citizen rights are of the highest value for modern states /41/. Not agreeing with the proposed, it should be noted that experience shows that bipatrides do not value the state in which they live. They are often malicious and corrupt. Because they always have a "spare option" to escape. It is difficult to find patriots among the bipatrides of the country in which they live, and it is impossible to rely on them in a difficult moment. As the experience of some countries shows, the presence of a large number of bipatrides with the passports of a certain other country can lead to separatism, 
armed conflicts, the annexation of the territory and the loss of sovereignty and independence. If the level of bipatrism of one country exceeds $15 \%$ of the population, the state should take this issue very seriously and try to reduce the number of bipatrides. It should be noted that there are specialists who support such point of view of the article's author. For example A.Yu. Poltorakov, K.A. Helvetius, P. Buast, who say that the institution of dual citizenship generates humanitarian and political disagreements and political and legal conflicts primarily because of the different scope of rights and freedoms by which bipatrides (persons with two citizenships) can actually use in their place of residence and for which they have the right according to the laws of their (ethnic, etc.) homeland, citizens of which they also remain. As a consequence, over the last century and a half, the practice of interstate relations has tended to avoid the use of the dual citizenship institution, and if it is impossible, it can only be used on the basis of bilateral agreements $/ 42 /$. In addition, other experts express a fair opinion that the spread of dual citizenship in a state crisis inevitably entails its further weakening and erosion. The danger of the looseness of the national community, splits, conflicts, and the weakening of social cohesion will usually be greater when residents are dual citizens who might feel more obligated to show loyalty to another country than if they had only citizenship of the country where they live $/ 43 /$. Victor Rogalev, a deputy of the Majilis of the Parliament of the Republic of Kazakhstan, says that the Constitution of the Republic of Kazakhstan has article 10, paragraph 3, which has a clear interpretation: a citizen of Kazakhstan is not recognized as a citizen of another state. There is also a law on citizenship, but for us the constitutional norms are above all other arguments. Maybe, it is not worth it to even discuss this issue. According to his estimates, the percentage of people with dual citizenship in Kazakhstan is low, these are units that, perhaps, want to use something materially in two countries at once. This is also punishable, but there are other factors. Uncertainty, doubtfulness in some everyday situations, and sometimes a complete lack of patriotism, disrespect for their homeland. Such people will not bring any good /44/.

From the position of these authors, we can explain the results obtained in the article. The results of the research, stated in the article, refer to the constitutional law and are aimed at its improvement both from the theoretical and practical point of view. And these results can also be used in the adoption of laws on citizenship or the introduction of changes to them.

\section{CONCLUSIONS}

It can be argued that the institute of citizenship is inextricably linked with the development of the state, is of great importance for the existence of the state, its development. Considering the importance of this institution in the relations between the state and each citizen, it has its consolidation, first of all, at the national level of the state through the constitutional regulation of the basic principles of citizenship. So, given that the state's chosen policy in the sphere of citizenship directly affects its state formation, as a rule, the general principles of citizenship are determined by constitutional law, but are backed by a special law. The institute of citizenship encourages not only the state development, but also the active work of citizens. Providing the corresponding set of rights and freedoms of citizens, the state simultaneously assumes obligations to protect its population. Citizenship is manifested in the close relationship between a citizen and the state, manifested in the availability of both rights and obligations of both parties, which provides for prosecution for noncompliance. With the development of legal science in the Republic of Kazakhstan, the principles of building the institution of citizenship have historically been formed, which to date have found their legal expression in national legislation. In addition to the general principles on which the institution of citizenship in the Republic of Kazakhstan is built, in particular such as the right to citizenship, acquisition and termination of citizenship solely on the grounds established by law, equality of citizenship, the state also guarantees for its part the retention of citizenship of persons living outside the country and the prohibition of the extradition of citizens of the Republic to other countries, the protection of such persons by the Republic, as well as the preservation of Kazakhstani citizenship at the conclusion or dissolution of marriages. The UK has its own peculiarities of the legislation on citizenship, given its territorial status. In the UK, 
the following categories of citizenship are established: citizens of the United Kingdom of Great Britain and Northern Ireland (British); Citizens of British Dependent Territories; Citizens of the British Overseas Territories (British Overseas). Ways of acquiring citizenship: by birth; by origin; by naturalization; by registration. The citizenship of the British dependent territories does not provide for the right of free entry into the territory of the United Kingdom, but allows for the simplification (in the order of registration) of obtaining the citizenship of the United Kingdom of Great Britain and Northern Ireland. A special status in the UK is enjoyed by citizens of the Republic of Ireland and citizens of the European Union. EU citizenship, established by the Maastricht Treaty of 1992, presupposes the right of free entry and exit from the territory of the UK citizens of EU member states. Termination of citizenship is possible in cases of refusal or deprivation, which is formalized by the decision of the State Secretary of the Internal Affairs. Dual and multiple citizenship is a negative phenomenon for the state. The absence of a single legal connection between a citizen and a particular country violates the proper legal regulation of relations arising on the basis of their connection. The presence of bipatrism contradicts the certainty of the state and does not correspond to its nature and essence, since the basis of any statehood is its people, its nation, its citizens. A political connection is formed between them and the state. Citizens of the country form this country. And so the presence of multiple citizenship leads to a misunderstanding of statehood, makes adjustments to the legal regulation of the same relationship, and can cause conflicts for political reasons. All countries should try to reduce the number of bipatrides on their territory. Accountability should be implemented for bipatrism. First and foremost, it means to deprive them of their citizenship. Do not allow bipatrides to civil service and state secrets.

\section{Notes}

/1/ Olson M. et al. (2015). Citizenship discourses: production and curriculum. British Journal of Sociology of Education. 36(7): 1036.
/2/ Urry J. 2015. Globalization and citizenship. Journal of World-Systems Research. 5(2): 312.

/3/ Smirnova Ye.S. 2012. Institute of Citizenship and Protection of Human Rights in the Eurasian Region: Issues of History and Practice. Herald of the Karagandy State University.

/4/ Nepomnyashchaya A.A. 2013. Problems of the Institute of Citizenship in the Russian Federation. Herald of the Omsk Law Academy. 1 (20): 7.

/5/ Bee C., Villano P. 2015. Active citizenship in Italy and the UK: Comparing political discourse and practices of political participation, civic activism and engagement in policy processes. Political and Civic Engagement: Multidisciplinary Perspectives. 446.

/6/ Zhang C., Lillie N. 2015. Industrial citizenship, cosmopolitanism and European integration. European Journal of Social Theory. 18(1): 95.

/7/ Yagudin I.R. 2014. The phenomenon of citizenship in the vectors of measuring the rights and freedoms of the individual. Herald of the Volga Management Institute. 2 (41): 54-55.

/8/ Kartashkin V.A., Lukasheva Ye.A. 2002. International instruments on human rights: A collection of documents. Moscow: NORMA Publishing house.

19/ Ebzeyev B.S. 1995. Citizenship and human rights: some methodological issues. Actual problems of citizenship. Materials of the Int. scientific and practical. conf. On problems of citizenship. Moscow, pp. 22-23.

/10/ Balgimbekova U. 2010. On the issue of determining the citizenship of underage children under the legislation of the Republic of Kazakhstan. Herald of the Karagandy State University.

/11/ Balgimbekova, G.U., Ybyray A.K. 2012. Legal regulation of the institution of citizenship in the constitutional norms of the Republic of Kazakstan and foreign countries. Herald of the Karagandy State University.

/12/ Scriven A.M. 2013. Top-Down Nationalism in PostSoviet Kazakhstan, pp. 10.

/13/ The population of Kazakhstan, URL: http://countrymeters.info/ru/Kazakhstan (access date 24.03.2017).

/14/ Official statistical information, URL:http://www.stat.gov.kz.

115/ On the Concept of the Legal Policy of the Republic of Kazakhstan for the period from 2010 to 2020: Decree of the President of the Republic of Kazakstan on August 24, 2009, No. 858. Kazakstanskaya Pravda, 2009, Aug. 27.

/16/ Balgimbekova G.U., Isabekova V.S. 2013. Citizenship of the Republic of Kazakhstan as one of the factors of stability of the development of independent statehood. Herald of the Karagandy State University. 
Aidana Otynshiyeva, Alua Ibrayeva, Joshua Castellino, Dina Baimakhanova, Akhilbek Baikenzheyev: INTERNATIONAL AND LEGAL ASPECTS OF CITIZENSHIP ON THE BASIS OF ANALYSIS OF THE LEGISLATION IN KAZAKHSTAN AND GREAT BRITAIN

Media, Culture and Public Relations, 8, 2017, 1, 72-84

/17/ Pennings F., Vonk G. (2015). Research Handbook on European Social Security Law.

/18/ Isin E.F., Saward M. 2013. Enacting European Citizenship. Cambridge University Press.

/19/ Suvarierol S. 2015. National Fields of Civic Integration: Operationalization of Citizenship Requirements.

/20/ Mantu S.A. 2009. Deprivation of Citizenship in the United Kingdom.

/21/ Stewart E., Mulvey G. 2014. Seeking safety beyond refuge: the impact of immigration and citizenship policy upon refugees in the UK. Journal of Ethnic and Migration Studies. 40(7): 1024.

/22/ Faist T., Schmidt K., Ulbricht C. 2016. Inclusion, Exclusion, and Citizenship: An Overview of European Practice. Europe-No Migrant's Land?, pp. 6-7.

/23/ Constitution of Republic of Kazakhstan. 1995. as amended and supplemented, the Law dated 07.10.1998, 05.2007, 02.02.2011, URL: www.constitution.kz)

/24/ URL: http://dknews.kz/politics/32-majilis/11446deputaty-predlagayut-lishat-grazhdanstva-zasovershenie-terakta.html (03.03.2017)

/25/ Law of the Republic of Kazakhstan dated December 20, 1991 "On Citizenship of the Republic of Kazakhstan", [ER]. Access mode: zakon.kz

/26/ Goodwin-Gill G.S. 2014. Mr Al-Jedda, Deprivation of Citizenship, and International Law. Revised draft of paper presented at a Seminar at Middlesex University on February. 14: 5.

/27/ Andreouli E., Howarth C. 2013. National identity, citizenship and immigration: Putting identity in context. Journal for the Theory of Social Behaviour. 43(3): 367.

/28/ Blinder S. 2013. Naturalisation as a British citizen: Concepts and trends. Migration Observatory Briefings. Oxford: COMPAS.

/29/ Andreouli E., Dashtipour P. 2014. British citizenship and the 'other': an analysis of the earned citizenship discourse. Journal of Community \& Applied Social Psychology. 24(2): 101.

130/ Brooks T. 2013. The life in the United Kingdom citizenship test: is it unfit for purpose?

/31/ Gray D., Griffin C. 2014. A journey to citizenship: Constructions of citizenship and identity in the British Citizenship. 2014. British Journal of Social Psychology. 53(2): 300.

/32/ Macklin A. 2014. Citizenship Revocation, the Privilege to Have Rights and the Production of the Alien". Queens Law Journal. 40: 7.
/33/ Banks J.A. 2015. Global migration, failed citizenship, and civic education. Paper presented as a keynote address at the Korean Association for Multicultural Education (KAME) Conference, Hanyang University, Seoul, Korea.

/34/ Tyler I., Marciniak K. 2013. Immigrant protest: an introduction. Citizenship Studies. 17(2): 143.

135/ Strumia F. 2016. Brexiting European Citizenship through the Voice of Others. German Law Journal. 17(Brexit Supplement): 109.

/36/ Ashcroft R., Bevir M. 2016. Pluralism, National Identity and Citizenship: Britain after Brexit. The Political Quarterly. 87(3): 359.

/37/ Kalmakov Ye.B. 2015. On the issue of the formation of the civil identity of the population of Kazakhstan (regional sociological aspect). Materials of the Astana Sociological Forum, dedicated to the Day of the First President of the Republic of Kazakhstan. Int. scientific and practical conf. Ex. ed. Z.K. Shaukenova. Astana, p.311.

138/ Law of the Republic of Kazakhstan dated December 20, 1991 "On Citizenship of the Republic of Kazakhstan", URL: zakon.kz

/39/ Kusmangaliyeva Zh.D. 2015. "Kazakhstan way2050": formation and development of the state in the mirror of Kazakhstan's sociology. Materials of the Astana Sociological Forum, dedicated to the Day of the First President of the Republic of Kazakhstan. Int. scientific and practical conf. Ex. ed. Z.K. Shaukenova, p. 39.

/40/ Scriven A.M. 2013. Top-Down Nationalism in PostSoviet Kazakhstan. pp. 37-40

/41/ Belov A.V. 2002. International legal aspects of dual citizenship: author's abstract on competition of a scientific degree of the candidate of legal sciences. Specialty 12.00.10 - International Law; European law. Saint-Petersburg: St. Petersburg State University.

/42/ Poltorakov A.Yu., Helvetius K.A., Buast P. 2013. The problem of dual citizenship as a political and legal challenge to social and humanitarian security. Law and politics. 8: 1015.

/43/ Sherer R. 1994. Practice and experience of countries of Western Europe in dealing with issues of dual citizenship. Materials of the seminar on citizenship, statelessness and the status of foreigners in the CIS and Baltic States, Helsinki, pp. $45-49$.

/44/ URL: http://kstnews.kz/newspaper/29?node=16091 


\title{
MEĐUNARODNI I PRAVNI ASPEKTI DRŽAVLJANSTVA NA TEMELJU ANALIZE ZAKONODAVSTVA U KAZAHSTANU I VELIKOJ BRITANIJI
}

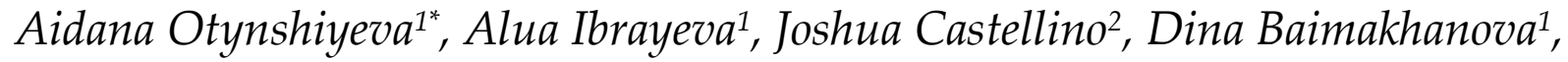 \\ Akhilbek Baikenzheyev ${ }^{3}$ \\ Department of the Theory and History of State and Law, Constitutional and Administrative Law Al-Farabi Kazakh National \\ University, Almaty, Kazakhstan'; Law School, Middlesex University, London, United Kingdom²; Academy of National Security in \\ the Republic of Kazakhstan, Alma-Ata, Kazakhstan ${ }^{3}$
}

Sažetak

Svrha ovog članka je ispitati međunarodne pravne aspekte državljanstva na temelju zakona Kazahstana i Ujedinjenog Kraljevstva. Autori su koristili opće teorijske i specifične znanstvene istraživačke metode. Kao rezultat analize, autor tvrdi da svaka država neovisno provodi zakonsku regulaciju državljanstva. Pravno uređenje državljanstva izravno je povezano s migracijom ljudi, što je posljednjih godina pojačano zbog oružanih sukoba i gospodarskog pada u nekim zemljama. Pravna regulacija državljanstva mora ispravno odražavati migracijske procese kako bi se spriječile negativne posljedice i za državu i za pojedinca u njoj. Dokazano je i opravdano da zakonodavstvo o državljanstvu Kazahstana i Ujedinjenog Kraljevstva osigurava niz zahtjeva za stjecanje državljanstva. Postoje dva glavna načina za dobivanje državljanstva: rođenjem ili naturalizacijom. Na temelju analize, autor je zaključio da zakonodavstvo o državljanstvu Kazahstana i Ujedinjenog Kraljevstva propisuje da se državljanstvo stječe i prestaje posebno propisanim pravnim postupkom od strane nadležnih državnih tijela. Na temelju analize kazahstanskog zakonodavstva zaključeno je da su metode dobivanja državljanstva Kazahstana: 1) rođenjem; 2) kao rezultat naturalizacije; 3) na temelju međudržavnih ugovora u Kazahstanu; 4) temeljem Zakona Kazahstana "o državljanstvu". Postoje i načini za dobivanje državljanstva u Velikoj Britaniji prema Zakonu o državljanstvu iz 1981. godine: 1) rođenjem; 2) po podrijetlu; 3) naturalizacijom; 4) registracijom. Također, na temelju znanstvenog pristupa pitanju državljanstva i njegove uloge u postojanju države, autor je zaključio da bipatrizam (višestruko državljanstvo) nepovoljno utječe na državu i nosi veliki rizik za državu, uključujući gubitak neovisnosti i suvereniteta.

\section{Ključne riječi}

bipatrizam, državljanstvo, naturalizacija, migracija, stjecanje državljanstva. 